\title{
ANALISIS DAMPAK SEKTOR PERTAMBANGAN MINERAL LOGAM TERHADAP PRODUK DOMESTIK BRUTO
}

\author{
Role Analysis of Metal Mineral Mining Sector on Gross \\ Domestic Product
}

\author{
TRISWAN SUSENO \\ Puslitbang Teknologi Mineral dan Batubara \\ Jalan Jenderal Sudirman 623 Bandung 40211 \\ Telp. (022) 6030483, Fax. (022) 6003373 \\ e-mail: triswan.suseno@esdm.go.id
}

\begin{abstract}
ABSTRAK
Sektor pertambangan mineral logam, walaupun kontribusinya kecil, akan tetapi masih menjadi salah satu sektor andalan dalam menggerakkan roda perekonomian Nasional. Dengan semakin berkurangnya sumber daya di sektor ini, diduga perannya semakin berkurang pula. Tujuan analisis ini adalah mengukur dampak kontribusi sektor terhadap pertumbuhan Produk Domestik Bruto di masa lalu, saat ini dan di masa yang akan datang. Untuk mengukur hubungan antara sumberdaya dengan peran sektor digunakan model regresi linear, sedangkan untuk mengetahui keberartian kontribusi sektor ini dilakukan dengan menguji koefisien regresinya. Data yang digunakan untuk mendukung perhitungan dan analisis adalah data Produk Domestik Bruto dari tahun 2000-2015, atas dasar harga konstan tahun 2000. Hasil perhitungan dan analisis menunjukkan bahwa besarnya kontribusi sektor ini sangat kecil dan tidak berpengaruh secara signifikan terhadap peningkatan Produk Domestik Bruto. Selama ini, usaha pertambangan yang hanya menjual bahan baku mineral memberikan dampak yang kecil terhadap Produk Domestik Bruto. Agar sektor ini dapat menjadi penggerak ekonomi yang lebih besar, harus dilakukan studi lanjut mengenai pembangunan industri pengolahan dan pemurnian (smelter) logam untuk meningkatkan nilai tambah sektor tersebut, sehingga mampu memberikan peran yang lebih besar terhadap Produk Domestik Bruto.
\end{abstract}

Kata kunci : produk domestik bruto, sektor pertambangan mineral logam, kontribusi, peran

\begin{abstract}
The mining sector of metal mineral, despite its small contribution, will still be one of the driving sector in the national economy. In accordance with the diminishing resources in this sector, it is assumed that its role will also decreasing. The objective of this analysis is to measure the influence of the sector contribution toward the gross domestic product growth in the past, current and the future. A linear regression model is used to measure the relationship between resources and sector roles. Meanwhile, in order to know the contribution significance in the sector, a regression coefficient is tested. The national gross domestic product on 2000-2015 according to the 2000 constant value is used for data in calculation and analysis. The calculation and the analysis shows that the contribution of this sector is very low and do not significantly influence the national gross domestic product. So far, the mining business which limited to sells raw materials of minerals provides little influence to the national gross domestic product. In order to become a bigger economic mover, it must conduct a further study on smelter development for metal products and increase the value added to this sector. Therefore, it can have a bigger role for the national gross domestic product.
\end{abstract}

Keywords: gross domestic product, sector of metallic mineral mining, contribution, role 


\section{PENDAHULUAN}

Indonesia merupakan negara yang diberikan karunia sumber daya alam yang sangat melimpah, salah satu di antaranya adalah sumber daya mineral dan batubara yang merupakan bagian dari sektor pertambangan. Sudah sejak lama sektor pertambangan menjadi salah satu sektor yang mendorong perputaran roda pembangunan dan perekonomian Indonesia.

Laju pertumbuhan sektor pertambangan mineral logam selama kurun waktu 2000-2015 berjalan sangat lambat yaitu hanya 1,93\% per tahun. Jauh di bawah laju pertumbuhan ekonomi Indonesia yang ditunjukkan oleh produk domestik bruto (PDB) sebesar 5,38\% (BPS, 2016a). Pada kurun waktu yang sama sektor ini hanya mampu memberikan kontribusi sebesar $1,41 \%$ terhadap PDB. Menurunnya kontribusi sektor pertambangan mineral logam diduga akibat dari terbitnya UU No. 4 tahun 2009 yang melarang semua perusahaan pertambangan untuk mengekspor mineral logam dalam bentuk bahan baku, sehingga sebagian besar aktivitas usaha pertambangan terhenti. Apalagi hingga saat ini UU No. 4 Tahun 2009 tentang mineral dan batubara dalam tahap revisi dan belum terlihat adanya tanda-tanda akan disahkan. Jika hal ini dibiarkan berlarut-larut, dikhawatirkan pendapat Kustanto $d k k_{\text {., }}$ (2012) akan terjadi dan ini tentu akan merugikan dunia pertambangan nasional. Pendapat dimaksud adalah bila penurunan kontribusi sektor pertambangan mineral logam terus berlanjut, maka sektor ini tidak bisa lagi menjadi motor penggerak dan memegang peran penting bagi perekonomian Indonesia di masa mendatang.

Mengingat sumber daya di sektor pertambangan ini tidak terbarukan dan seiring berjalannya waktu lambat laun sumber daya mineral ini secara perlahan akan mengalami penurunan potensi maupun kualitasnya dan dikhawatirkan dampaknya semakin menurun terhadap pembangunan ekonomi. Untuk mengetahui dampak tersebut di masa mendatang, perlu dilakukan analisis dampak kontribusi sektor pertambangan mineral logam terhadap PDB.

Analisis ini diarahkan untuk menguji dampak atau peran keberadaan sektor pertambangan, terutama sektor pertambangan mineral logam terhadap pembangunan ekonomi yang terhimpun dalam PDB. Peran yang dimaksud adalah besarnya sumbangan yang diperoleh dari usaha sektor pertambangan mineral logam terhadap pembentukan struktur PDB. Untuk mengukur peran tersebut digunakan data pertumbuhan dan kontribusi sektor pertambangan mineral logam yang tergabung dalam struktur PDB dari tahun 2000 sampai dengan tahun 2015, atas dasar harga konstan tahun 2000.

\section{METODE}

Metode yang digunakan adalah metode regresi ganda yang menggambarkan hubungan antara PDB dengan PDB sektor pertambangan batubara, pertambangan mineral logam dan penggalian. Analisis dilakukan dengan analisis deskriptif dan analisis data panel, yaitu kombinasi dari data time series dan cross section. Analisis regresi berganda digunakan untuk menguji pengaruh dua atau lebih peubah bebas terhadap satu peubah tak bebas (Melati, 2013).

\section{Pengertian Produk Domestik Bruto}

Menurut Badan Pusat Statistik (2016), Produk Domestik Bruto (PDB) adalah jumlah nilai tambah yang dihasilkan oleh seluruh unit usaha dalam suatu negara tertentu, atau merupakan jumlah nilai barang dan jasa akhir yang dihasilkan oleh seluruh unit ekonomi. Data PDB merupakan salah satu gambaran pendapatan dan output bagi perekonomian negara tertentu di satu periode waktu tertentu. Definisi dari PDB berdasarkan total nilai pasar dari semua barang dan jasa yang diproduksi di dalam negeri dalam jangka waktu tertentu (biasanya satu tahun) (Kira, 2013). PDB atas dasar harga berlaku dapat digunakan untuk melihat pergeseran dan struktur ekonomi, sedangkan harga konstan digunakan untuk mengetahui pertumbuhan ekonomi dari tahun ke tahun. Menurut Aryanto (2011) dalam Sulaksono (2015), yang lebih relevan untuk digunakan adalah nilai PDB berdasarkan harga konstan daripada PDB atas dasar harga berlaku. Kajian dampak suatu sektor terhadap PDB pernah dilakukan oleh Raswatie (2014), yaitu sektor pertanian. Hermawan (2014), melakukan analisis dampak sektor 
pertambangan terhadap pertumbuhan indek pembangunan manusia (IPM) dengan menggunakan data pertumbuhan Produk Domestik Regional Bruto (PDRB) provinsiprovinsi di Indonesia atas dasar harga konstan tahun 2000. Kajian dampak sektor pertambangan di daerah Kabupaten Luwu pernah dilakukan oleh Hidayat, Rustiadi dan Kartodihardjo (2014).

Sektor pertambangan mineral logam adalah salah satu sektor yang menjadi bagian dari terbentuknya struktur PDB. Kontribusi sektor pertambangan mineral logam diukur oleh besarnya sumbangan sektor ini terhadap PDB, peran sektor ini ditentukan oleh seberapa besar sumbangan/kontribusi sektor pertambangan mineral logam terhadap PDB.

\section{Model Regresi Linear berganda}

Analisis regresi linier berganda adalah hubungan secara linear antara dua atau lebih peubah bebas (independent variable) $\mathrm{X}$ dengan peubah tak bebas (dependent variable) Y. Analisis ini untuk mengetahui arah hubungan antara peubah bebas dengan peubah tak bebas apakah masing-masing variabel independen berhubungan positif atau negatif dan untuk memprediksi nilai dari peubah tak bebas apabila nilai peubah bebas mengalami kenaikan atau penurunan (Gujarati, 2003; Sudjana, 2005). Dalam statistika, metode regresi kuadrat terkecil digunakan untuk menduga nilai-nilai dalam suatu set data berdasarkan nilai satu atau lebih data yang lain (Arisandi dan Purhadi, 2014).

Idris (2008) menjelaskan bahwa regresi linear berganda menggambarkan hubungan antara peubah tak bebas dengan faktor-faktor yang memengaruhi lebih dari satu peubah bebas. Model digunakan untuk mengukur intensitas hubungan antara dua peubah atau lebih dan digunakan untuk memprediksi atau memperkirakan nilai $Y$ atas nilai $X$. Persamaan regresi linear berganda yang mencakup dua peubah tersebut adalah sebagai berikut:

$Y=\alpha+\beta_{1} X_{1}+\beta_{2} X_{2}+\ldots .+\beta_{n} X_{n}$

Dalam hal ini,

$\begin{array}{rlr}\mathrm{Y} & = & \text { Variabel dependen } \\ & \text { yang diprediksikan) }\end{array}$

$\alpha$

$\beta$

n

$=$ Konstanta (nilai $\mathrm{Y}$ apabila $\mathrm{X}_{1}$, $\mathrm{X}_{2} \ldots . . . \mathrm{X}_{\mathrm{n}}=0$ )

$=$ Koefisien regresi (nilai peningkatan ataupun penurunan)

= banyaknya sampel

Yudisthira dan Budhiasa (2013) menggunakan Persamaan (1) untuk mengetahui dampak konsumsi, investasi dan inflasi terhadap Produk Domestik Bruto di Indonesia. Sedangkan Saheed, Abarshi dan Ejide (2014), menggunakan model ini untuk mengetahui dampak pertambangan minyak terhadap perkembangan ekonomi di Nigeria tahun 1970 - 2012.

\section{Uji Keberartian (Signifikan)}

Untuk mengetahui sejauh mana dampak variabel bebas $X$ terhadap variabel tidak bebas $Y$ dilakukan dengan menguji tingkat nyata koefisien regresi di bawah ini, hipotesis tersebut dinyatakan dalam bentuk sebagai berikut:

$\mathrm{H}_{0}: \beta=\beta_{i} ; \quad$ Tidak memberikan dampak yang signifikan.

$\mathrm{H}_{1}: \beta \neq \beta \mathrm{i} ; \quad$ Ada dampak.

Untuk pengujiannya digunakan statistik,

$t=\frac{b-\beta i}{s_{b}}$

Dengan derajat kebebasan (dk) atau degree of freedom = jumlah sampel - banyaknya variabel - konstanta $(n-k-1)$, untuk distribusi $t$ diambil (n-k-1). Dalam hal ini $k$ adalah banyaknya variabel bebas.

Kriteria uji :

Tolak hipotesis $\mathrm{H}_{0}$, jika t (hitung) $\geq \mathrm{t}(1-1 / 2 \alpha)$ atau $\mathrm{t}$ (hitung) $\leq \mathrm{t}(1-1 / 2 \alpha)$ dengan distribusi $\mathrm{t}$ yang digunakan mempunyai $d k=(n-k-1)$. Tingkat signifikansi (a) menunjukkan probabilitas atau peluang kesalahan yang ditetapkan peneliti dalam mengambil keputusan untuk menerima atau menolak hipotesis (Mayanti, Syaparuddin dan Ahmad, 2013).

Uji "t" digunakan untuk menguji dampak variabel bebas terhadap variabel terikat secara sendiri-sendiri atau secara parsial (Zulkarnain, Purwanti dan Indrayani, 2013). Dalam hal ini, Yulianita (2009) juga menggunakan statistik ini 
untuk menguji sektor unggulan di Kabupaten Ogan Komering Ilir. Nilai-nilai statistik " $\mathrm{t}$ " dapat diperoleh di dalam buku Supranto (1983).

\section{Data}

Data yang digunakan adalah untuk mengetahui dampak PDB sektor pertambangan mineral dan batubara dan PDB diperoleh dari Badan Pusat Statistik dalam bukunya yang berjudul PDB Indonesia Menurut Lapangan Usaha Tahun 2000 - 2015 atas dasar harga konstan tahun 2000 (BPS, 2016a, 2016b). Data dapat dilihat dalam Tabel 1.

\section{HASIL DAN PEMBAHASAN}

PDB merupakan salah satu data ekonomi yang dapat digunakan untuk mengevaluasi kinerja pembangunan ekonomi suatu negara/wilayah yang diukur berdasarkan lapangan usaha di dalam negeri. Salah satu sektor yang akan diukur perannya adalah sektor pertambangan mineral logam yang menjadi andalan dalam mendorong pembangunan ekonomi di Indonesia.

Sebagaimana diketahui bahwa dampak terbitnya UU No. 4 Tahun 2009, banyak kegiatan usaha di sektor pertambangan menghentikan kegiatannya. Penurunan kontribusi dan pertumbuhan sektor industri ini mengarah pada suatu gejala deindustrialisasi yaitu proses perubahan sosial dan ekonomi yang disebabkan oleh penurunan kapasitas atau aktivitas industri dalam suatu wilayah atau negara (Kustanto $d k k$., 2012). Hal ini dikhawatirkan juga terjadi pada sektor pertambangan mineral logam, yaitu gejala tersebut sudah terlihat banyak perusahaan pertambangan menghentikan kegiatannya.

Sektor pertambangan mineral logam, yang menjadi salah satu andalan dalam mendukung perekonomian ternyata selama tahun 20002015 hanya mampu memberikan kontribusi rata-rata sebesar $1,41 \%$. Kontribusi tertinggi sektor ini pernah terjadi pada tahun 2002, namun itu juga tidak begitu besar yaitu hanya $1,69 \%$. Hal ini dipicu oleh tingginya permintaan bahan baku beberapa komoditas logam dari negara lain dan tingginya harga pada saat itu. Namun seiring dengan semakin terkurasnya sumber daya secara perlahan kontribusi sektor ini mengalami penurunan secara perlahan hingga tahun 2008 menjadi 1,35\%. Walaupun sempat mengalami kenaikan menjadi 1,38 pada tahun 2009, namun memasuki tahun 2010 sampai dengan tahun 2015 peran sektor ini secara perlahan terus mengalami penurunan hingga mencapai $1,06 \%$ saja kontribusinya terhadap PDB (Gambar 1). Salah satu penyebabnya adalah dengan terbitnya UU No. 4 Tahun 2009 tentang pertambangan mineral dan batubara yang melarang ekspor mineral dalam bentuk bahan baku, sehingga volume ekspor sektor pertambangan mineral logam mengalami penurunan.

Tabel 1. PDB sektor pertambangan mineral dan batubara dan PDB (miliar rupiah)

\begin{tabular}{ccccc}
\hline Tahun & Pertambangan Batubara & Pertambangan Mineral Logam & Penggalian & Produk Domestik Bruto \\
\hline 2000 & 27.378 & 22.469 & 6.046 & 1.389 .770 \\
2001 & 31.402 & 24.154 & 6.573 & 1.440 .406 \\
2002 & 34.454 & 25.432 & 7.235 & 1.505 .216 \\
2003 & 35.817 & 26.003 & 8.009 & 1.577 .171 \\
2004 & 32.966 & 24.809 & 9.017 & 1.656 .517 \\
2005 & 37.132 & 26.724 & 10.134 & 1.750 .815 \\
2006 & 38.855 & 27.349 & 11.436 & 1.847 .127 \\
2007 & 40.803 & 28.054 & 12.881 & 1.964 .327 \\
2008 & 40.505 & 28.060 & 14.260 & 2.082 .456 \\
2009 & 45.021 & 30.132 & 15.650 & 2.178 .850 \\
2010 & 48.158 & 31.246 & 17.025 & 2.314 .459 \\
2011 & 49.986 & 32.287 & 18.674 & 2.464 .566 \\
2012 & 51.034 & 35.439 & 20.475 & 2.618 .932 \\
2013 & 56.874 & 33.596 & 22.094 & 2.769 .053 \\
2014 & 56.942 & 33.678 & 23.827 & 2.909 .182 \\
2015 & 59.782 & 29.155 & 25.828 & 3.048 .645 \\
\hline
\end{tabular}

Sumber : (BPS, 2016a) dan (BPS, 2016b) 


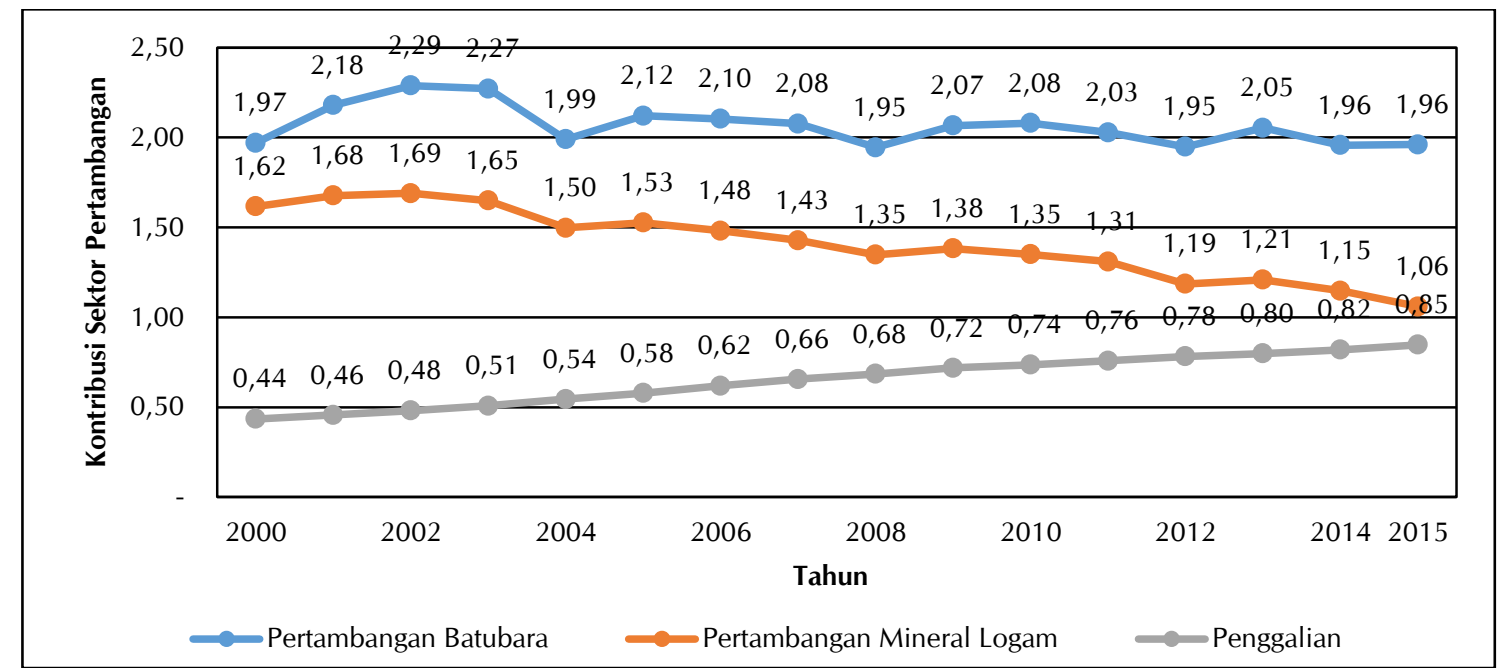

Sumber : BPS (2016b), diolah kembali

Gambar 1. Laju pertumbuhan sektor pertambangan mineral dan batubara dan kontribusinya terhadap PDB (\%), tahun 2000-2015.

Pada tahun 2001, laju pertumbuhan sektor pertambangan mineral logam mencapai $7,50 \%$ namun turunnya beberapa harga komoditas mineral logam membuat sektor ini mengalami kemerosotan pertumbuhan hingga 4,59\% pada tahun 2004. Walaupun sempat mengalami kenaikan sebesar $7,72 \%$ pada tahun 2005 , namun tahun-tahun berikutnya sektor ini mengalami perlambatan pertumbuhan bahkan pada tahun 2008 hingga mencapai $0,02 \%$. Penurunan ini terus berlangsung hingga tahun 2015 (Gambar 2). Hal ini diakibatkan oleh perlambatan ekonomi global (dan terutama perlambatan ekonomi Cina) menyebabkan penurunan harga-harga komoditi ke level yang rendah selama bertahun-tahun (Haeruman, 2014). Sebagai negara eksportir komoditi yang besar (yang tidak didukung oleh industri hilir yang berkembang baik), performa ekspor Indonesia sangat terpengaruh saat harga komoditas (seperti batubara dan logam lainnya) rendah. Di samping dampak dari terbitnya UU No. 4 Tahun 2009 tentang Mineral dan Batubara, juga karena rendahnya harga komoditas-komiditas tidak hanya disebabkan oleh permintaan global yang lebih lemah namun juga karena kelebihan suplai.

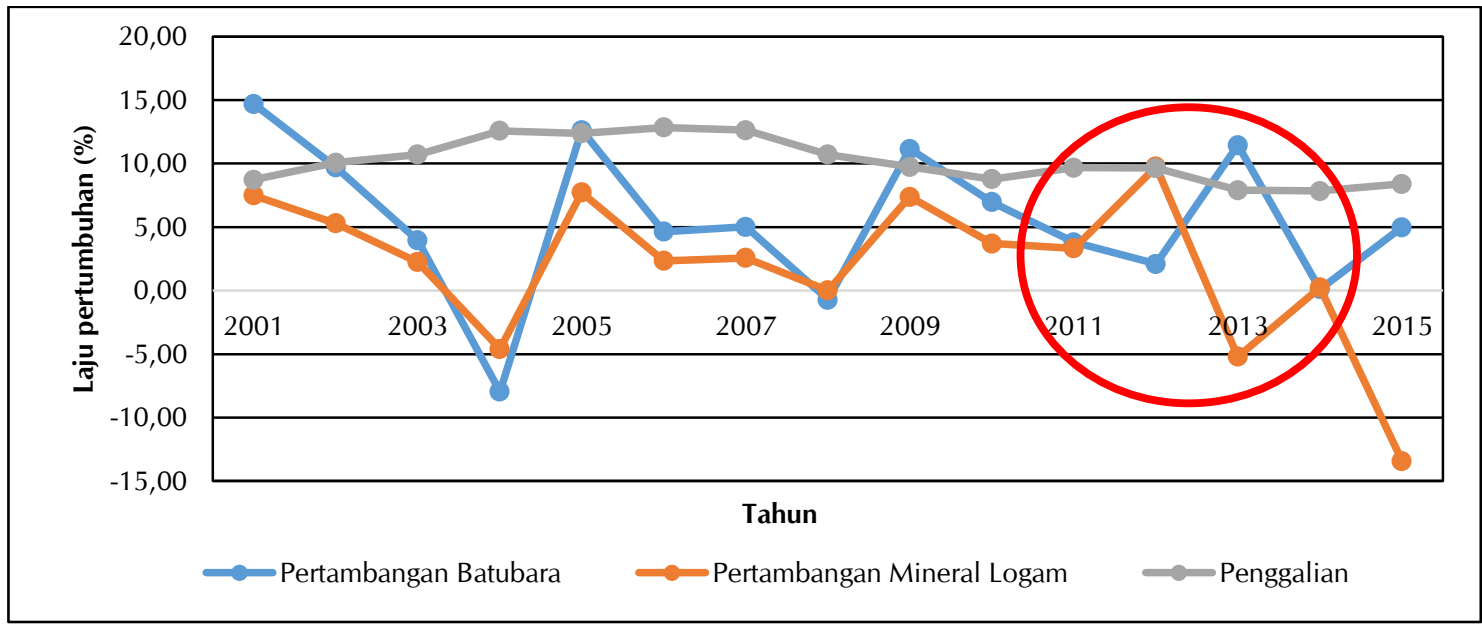

Sumber : BPS (2016b), diolah kembali

Gambar 2. Laju pertumbuhan sektor pertambangan mineral dan batubara tahun 2001-2015 (\%) 
Dalam Gambar 2 tampak bahwa pada tahun 2012 laju pertumbuhan sektor pertambangan mineral logam mengalami kenaikan PDRB sebesar 10,86\% dibandingkan dengan tahun 2011 yang hingga 1\%. Pada tahun 2013 laju pertumbuhan turun lagi menjadi 5,20\%, kondisi seperti itu terus berlangsung hingga tahun 2015 menjadi 13,94\%. Jika tidak terjadi perubahan dalam pengelolaan di sektor mineral dan batubara dikhawatirkan peran sektor ini akan semakin berkurang. Salah satu upaya untuk meningkatkan kualitas sumber daya mineral logam adalah melalui kebijakan pemerintah melalui penerbitan Permen ESDM No. 8 tahun 2015 tentang peningkatan nilai tambah mineral melalui pengolahan dan pemurnian di dalam negeri.

Selama ini, komoditas mineral logam yang dimiliki Indonesia diekspor ke berbagai negara dalam bentuk bahan baku yang harganya relatif sangat rendah yang mengakibatkan pendapatan negara dari hasil penjualan (ekspor) tersebut juga menjadi kecil. Peran sektor pertambangan mineral logam menjadi pendorong terhadap produk domestik bruto dapat diukur dan diuji melalui metode analisis regresi dan pengujian hipotesis di bawah ini.

Dengan menggunakan persamaan (1), maka model regresi yang digunakan adalah :

$Y^{\prime}=a+b_{1} X_{1}{ }^{\prime}+b_{2} X_{2}{ }^{\prime}+b_{3} X{ }^{\prime}$

Dalam hal ini,

$\mathrm{Y}^{\prime}=$ Variabel tak bebas PDB (nilai yang diprediksikan)

$\mathrm{X}_{1}{ }^{\prime}=$ Variabel bebas PDB sektor pertambangan batubara

$\mathrm{X}_{2}{ }^{\prime}=$ Variabel bebas PDB sektor pertambangan mineral logam
$\mathrm{X}_{3}{ }^{\prime}=$ Variabel bebas PDB Sektor Penggalian

$A=$ Konstanta (nilai $Y^{\prime}$ apabila $X_{1}, X_{2}$ dan $X_{3}$ $=0$ )

$\mathrm{b}_{1}=$ Koefisien regresi sektor pertambangan batubara

$\mathrm{b}_{2}=$ Koefisien regresi sektor pertambangan mineral logam

$\mathrm{b}_{3}=$ Koefisien regresi sektor penggalian

$\mathrm{n}$ = banyaknya sampel

Data dari tahun 2000-2015 yang terdapat di dalam Tabel 1 digunakan untuk menghitung nilai-nilai koefisien yang ada dalam model regresi (persamaan 3). Perhitungan dilakukan dengan bantuan perangkat lunak program aplikasi Statistical Product and Service Solutions (SPSS), hasilnya dapat dilihat dalam tabel-tabel di bawah ini. Perhitungan untuk mendapatkan Anova dapat dilihat dalam Tabel 2.

Tabel 2 adalah untuk mendapatkan nilai statistik $F$ (hitung) yang digunakan untuk menguji kelinearan model. Dari daftar distribusi $\mathrm{F}$ dengan $\mathrm{dk}$ pembilang $=\mathrm{k}=2 \mathrm{dk}$ penyebut $=n-k-1=16-2-1=13$ dan $\alpha=0,05$ didapat nilai tabel $\mathrm{F}$ dari lampiran $1=3,81$. Nilai 3,81 ini diperoleh dari dalam Lampiran 1, baris ke 13 kolom 2 (Gaspersz, 1992). Kemudian nilai tabel $\mathrm{F}$ hasil perhitungan dibandingkan dengan nilai tabel $F$ yang ada dalam Lampiran 1. Ternyata $F$ (hitung) = 157,83 lebih besar dari $F$ (tabel) $=3,81$. Artinya bahwa model regresi linear ganda yang digunakan bersifat nyata dengan kata lain bahwa model tersebut dapat digunakan sebagai alat untuk memprediksi PDB. Berdasarkan model tersebut diperoleh nilainilai koefisien sebagai berikut,

Tabel 2. Anova ${ }^{a}$

\begin{tabular}{crrccc}
\hline Model & Sum of Squares & \multicolumn{1}{c}{$\mathrm{df}$} & Mean Square & $\mathrm{F}$ & \multicolumn{1}{c}{ Sig. } \\
\hline Regression & 4422286,419 & 3 & 1474095,473 & 9339,886 & \multirow{2}{*}{$000^{\mathrm{b}}$} \\
Residual & 1893,936 & 12 & 157,828 & & \\
\hline Total & 4424180,355 & 15 & & & \\
\hline
\end{tabular}

a. Dependent Variable: PDB

b. Predictors: (Constant), penggalian, mineral, batubara

$\mathrm{df}=$ degree of freedom

Anova $=$ Analysis of variance 
Tabel 3. Coefficients ${ }^{a}$

\begin{tabular}{|c|c|c|c|c|c|}
\hline \multirow{2}{*}{ Model } & \multicolumn{2}{|c|}{ Unstandardized Coefficients } & \multirow{2}{*}{$\begin{array}{c}\text { Standardized Coefficients } \\
\text { Beta }\end{array}$} & \multirow{2}{*}{$\mathrm{t}$} & \multirow{2}{*}{ Sig. } \\
\hline & B & Std. Error & & & \\
\hline (Constant) & 805,878 & 50,001 & & 16,117 & ,000 \\
\hline Batubara & 2,296 & 2,153 & 042 & 1,066 & 307 \\
\hline Mineral & 1,612 & 1,813 & 011 & 889 & 391 \\
\hline Penggalian & 79,882 & 3,140 & 949 & 25,441 & 000 \\
\hline
\end{tabular}

a. Dependent Variable: PDB

Nilai-nilai koefisien di dalam Tabel 3 di atas, digunakan untuk membentuk model regresi ganda di bawah ini,

$Y^{\prime}=805,88+2,30 X_{1}{ }^{\prime}+1,61 X_{2}{ }^{\prime}+79,88 X_{3}{ }^{\prime}(4)$

dalam hal ini,

$Y^{\prime}$ adalah variabel (tak bebas) PDB;

$\mathrm{X}^{\prime}{ }^{\prime}$ adalah variabel bebas PDB sektor pertambangan batubara;

$\mathrm{X}_{2}{ }^{\prime}$ adalah variabel bebas PDB sektor pertambangan mineral logam;

$\mathrm{X}{ }^{\prime}$ adalah variabel bebas PDB sektor penggalian.

Model regresi ganda di atas (Persamaan 4) dapat digunakan untuk memperkirakan nilai PDB pada pada tahun 2016 sampai dengan tahun 2029. Setelah nilai PDB sektor pertambangan batubara, pertambangan mineral logam dan penggalian diketahui terlebih dahulu.

Sebelum persamaan 4 ini, sebaiknya diuji terlebih dahulu apakah setiap perubahan nilai sektor pertambangan mineral logam memberikan dampak yang signifikan terhadap PDB. Artinya bahwa harus dilakukan pengujian terhadap koefisien regresi dari sektor ini, seperti yang akan dilakukan di bawah ini.

\section{Uji Signifikansi Dampak Sektor Pertambangan Mineral dan Batubara}

Untuk mengetahui sejauh mana dampak usaha sektor pertambangan mineral logam terhadap PDB dapat dilakukan dengan menguji koefisien regresi di bawah ini, pernyataannya adalah sebagai berikut :

$H_{0}: \beta=\beta_{2}=0 ;$ Usaha sektor pertambangan mineral logam tidak berpengaruh secara signifikan terhadap PDB.

$H_{1}: \beta \neq \beta_{2}=0$; Tidak demikian.
Untuk pengujiannya digunakan statistik (Istiarini dan Sukanti, 2012),

$t=\frac{b-\beta_{2}}{s_{b}}$

Nilai-nilai dalam rumus di atas menggunakan angka-angka yang ada dalam Tabel 3, hasilnya adalah :

$\mathrm{t}=(1,61-0) / 1,813=0,89$

Dengan derajat bebas $(\mathrm{db})=$ jumlah sampel banyaknya variabel - konstanta $(n-k-1)$, untuk distribusi t diambil (n-k-1), kriteria uji :

Tolak hipotesis $\mathrm{H}_{0}$, jika $\mathrm{t}$ (hitung) $\geq \mathrm{t}\left(1-\frac{1}{2} \alpha\right)$ ataut(hitung) $\leq \mathrm{t}(1-1 / 2 \alpha)$ dengan distribusi $\mathrm{t}$ yang digunakan mempunyai $d k=(n-k-1)$.

Nilai $\mathrm{t}$ tabel dapat dicari dengan cara berikut ini:

1. $\alpha=0,05$; untuk uji 2 sisi $=0,025$

2. Degree of Freedom $(d f)=$ jumlah sampel - jumlah variabel bebas - 1 (angka 1 adalah konstanta) $=16-3-1=12$.

3. Cari persilangan antara $\mathrm{df}=12$ dan 0,025 .

4. Pencarian nilai $t$ tabel dengan Excel mudah sekali. Ketik rumus $=\operatorname{tinv}(0,05 ; 12)$, diperoleh nilai $\mathrm{t}=2,18$.

Ternyata nilai $\mathrm{t}$ (hitung) sektor pertambangan mineral logam dalam Tabel 3 adalah 0,89, nilainya lebih kecil dari nilai statistik tabel tStudent yaitu 2,18. Nilai 2,18 ini diperoleh dari dalam Lampiran 1, Distribusi t-Student (Gaspersz, 1992). Dengan demikian, hipotesis $\mathrm{H}_{0}$ diterima, artinya bahwa keberadaan sektor pertambangan mineral logam tidak memberikan dampak yang signifikan terhadap pembentukan struktur PDB.

\section{Kecenderungan Kontribusi Sektor Pertambangan Mineral Logam}

Pengujian hipotesis terhadap ketiga koefisien regresi variabel bebas menunjukkan dampak 
yang signifikan terhadap setiap perubahan PDB. Untuk mendapatkan nilai-nilai proyeksi PDB maka harus dihitung dulu nilai-nilai proyeksi ketiga variable bebas tersebut berdasarkan waktu. Dengan menggunakan data dalam Tabel 1 dan dengan menggunakan model regresi linear sederhana, maka proyeksi ketiga variabel bebas tersebut terhadap waktu adalah sebagai berikut:

1. model proyeksi sektor pertambangan batubara $\left(\mathrm{X} 1^{\prime}\right)$ berdasarkan waktu (t) adalah $\mathrm{X}^{\prime}{ }^{\prime}=25,52+2,05 \mathrm{t}$.

2. model proyeksi sektor pertambangan mineral logam $\left(\mathrm{X}_{2}{ }^{\prime \prime}\right)$ berdasarkan waktu $(\mathrm{t})$ adalah $\mathrm{X}_{2}^{\prime}=22,63+0,71 \mathrm{t}$; hubungan antara waktu (t) dengan.

3. model proyeksi sektor penggalian $\left(\mathrm{X}_{3}{ }^{\prime \prime}\right)$ berdasarkan waktu (t) adalah $\mathrm{X}_{3}{ }^{\prime}=2,91+$ 1,34 t.

Untuk menghitung proyeksi PDB $\mathrm{Y}^{\prime}=805,88$ $+2,30 X_{1}{ }^{\prime}+1,61 X_{2}{ }^{\prime}+79,88 X_{3}{ }^{\prime}$, pada tahun 2016, terlebih dulu dihitung nilai proyeksi ketiga variabel tersebut pada tahun 2016 dengan $\mathrm{t}=17$ :

1. $X_{1}{ }^{\prime}=25,52+2,05(17)=60,37$

2. $X_{2}{ }^{\prime}=22,63+0,71(17)=34,7$

3. $X_{3}{ }^{\prime}=2,91+1,34(17)=25,69$

sehingga nilai PDB $\mathrm{Y}^{\prime}=805,88+2,30$ $(60,37)+1,61(34,7)+79,88(25,69)=3.052,7$. Dengan cara yang sama, dapat dihitung pula nilai proyeksi PDB untuk tahun dari tahun 2017 $(\mathrm{t}=18)$ sampai dengan tahun $2029 \quad(\mathrm{t}=30)$. Secara lengkap hasil perhitungannya dapat dilihat dalam Tabel 4.

Untuk memperkuat hasil pengujian terhadap koefisien regresi sektor pertambangan mineral logam terhadap PDB di atas, Tabel 4 di bawah ini menunjukkan perkiraan atau proyeksi PDB berdasarkan model dalam persamaan (4). Proyeksi sektor pertambangan batubara, mineral logam dan penggalian telah dihitung dengan menggunakan model regresi Ilinear sederhana berdasarkan waktu.

Hingga tahun 2029, sektor pertambangan mineral logam diperkirakan akan mengalami kenaikan walaupun sangat lambat dengan laju pertumbuhan rata-rata sekitar $1,83 \%$ per tahun. Namun kenaikan tersebut belum mampu untuk meningkatkan peran atau kontribusi sektor ini terhadap PDB, hal ini dapat dilihat dari besarnya kontribusi sektor ini pada tahun 2016 sebesar $1,14 \%$ kemudian turun lagi menjadi $1,12 \%$ (2017). Nilai-nilai ini diperoleh dari kontribusi adalah rasio PDB sektor pertambangan mineral logam tahun 2016, yaitu 34,7/3.052,7=1,14\% dan tahun 2017 adalah 35,4/3.165,6=1,12\%, begitu seterusnya perhitungan ini dilakukan sampai tahun 2029, 43,9/4.520,4=0,97. Secara lengkap hasilnya dapat dilihat dalam Gambar 3.

Tabel 4. Proyeksi PDB berdasarkan proyeksi kenaikan sektor pertambangan batubara, mineral logam dan penggalian (triliun Rupiah)

\begin{tabular}{cccccc}
\hline Tahun & Batubara 1) & Mineral Logam 2) & Penggalian 3) & PDB 4) & Rasio(\%) 5$)=2) / 4)^{*} 100 \%$ \\
\hline 2016 & 60,37 & 34,7 & 25,69 & $3.052,7$ & 1,14 \\
2017 & 62,42 & 35,4 & 27,03 & $3.165,6$ & 1,12 \\
2018 & 64,47 & 36,1 & 28,37 & $3.278,5$ & 1,10 \\
2019 & 66,52 & 36,8 & 29,71 & $3.391,4$ & 1,09 \\
2020 & 68,57 & 37,5 & 31,05 & $3.504,3$ & 1,07 \\
2021 & 70,62 & 38,3 & 32,39 & $3.617,2$ & 1,06 \\
2022 & 72,67 & 39,0 & 33,73 & $3.730,1$ & 1,04 \\
2023 & 74,72 & 39,7 & 35,07 & $3.843,0$ & 1,03 \\
2024 & 76,77 & 40,4 & 36,41 & $3.955,9$ & 1,02 \\
2025 & 78,82 & 41,1 & 37,75 & $4.068,8$ & 1,01 \\
2026 & 80,87 & 41,8 & 39,09 & $4.181,7$ & 1,00 \\
2027 & 82,92 & 42,5 & 40,43 & $4.294,6$ & 0,99 \\
2028 & 84,97 & 43,2 & 41,77 & $4.407,5$ & 0,98 \\
2029 & 87,02 & 43,9 & 43,11 & $4.520,4$ & 0,97 \\
\hline
\end{tabular}

Keterangan :

1. $\mathrm{X}_{1}^{\prime}=25,52+2,05 \mathrm{t}$; hubungan antara waktu (t) dengan sektor Pertambangan Batubara.

2. $\mathrm{X}_{2}{ }^{\prime}=22,63+0,71 \mathrm{t}$; hubungan antara waktu $(\mathrm{t})$ dengan Sektor Pertambangan Mineral Logam.

3. $\mathrm{X}_{3}{ }^{\prime}=2,91+1,34 \mathrm{t}$; hubungan antara waktu (t) dengan sektor Penggalian.

4. $\mathrm{Y}^{\prime}=805,88+2,3 \mathrm{X}_{1}{ }^{\prime}+1,61 \mathrm{X}_{2}{ }^{\prime}+79,88 \mathrm{X}_{3}{ }^{\prime}$; seperti yang sudah dijelaskan sebelumnya. 


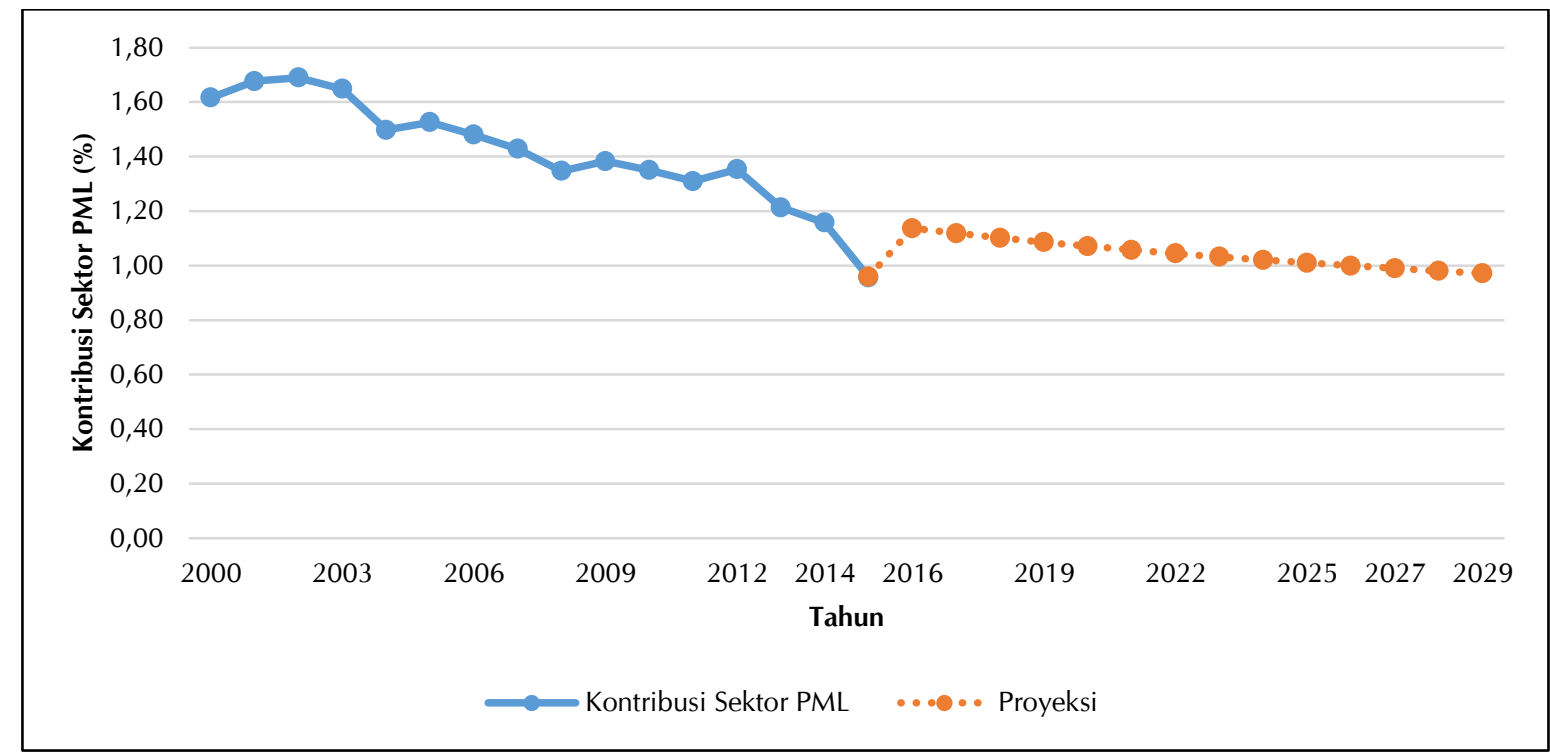

Sumber : BPS (2016), diolah kembali.

Keterangan : $\mathrm{PML}=$ pertambangan mineral logam.

Gambar 3. Realisasi (2000-2015) dan proyeksi (2016-2029) kontribusi sektor pertambangan mineral logam terhadap PDB

Hingga tahun 2029, rasionya terus berkurang, artinya bahwa apabila hanya mengandalkan penjualan (ekspor) komoditas mineral dalam bentuk bahan baku (mentah) tentunya sektor ini tidak akan mampu mendorong pertumbuhan PDB secara signifikan, sehingga peran sektor Pertambangan Mineral Logam akan terus mengalami kemerosotan karena kontribusi sektor ini semakin kecil. Gambar 3 merupakan gabungan rasio atau kontribusi sektor Pertambangan Mineral Logam yang realistis dari tahun 2000-2015 dengan proyeksi tahun 2016-2029.

Menyitir pada pernyataan Kustanto $d k k$. (2012), gejala-gejala deindustrialisasi telah nampak pula terjadi pada perekonomian Indonesia, yang secara umum peranan sektor pertambangan mineral logam dalam sumbangannya terhadap PDB mengalami penurunan. Bila penurunan kontribusi sektor ini di Indonesia terus berlanjut, maka sektor pertambangan mineral logam tidak bisa lagi diharapkan menjadi motor penggerak dan memegang peranan penting bagi perekonomian Indonesia di masa-masa mendatang. Oleh karena itu, perlu dilakukan upaya antisipasi agar kondisi deindustrialisasi tidak berlanjut dan berdampak buruk pada perekonomian Indonesia. Apabila tidak ada upaya yang serius dalam menyelesaikan masalah ini dan tidak ada kepastian hukum bagi para pelaku usaha tambang maka dampaknya adalah dunia pertambangan Indonesia akan menjadi semakin suram. Sundari (2012) berpendapat bahwa sektor industri pertambangan logam (non migas) dalam hal ini smelter memiliki peranan yang penting dalam pembangunan ekonomi di Indonesia dan mampu memberikan kontribusi yang cukup besar terhadap pertumbuhan ekonomi Indonesia.

\section{KESIMPULAN DAN SARAN}

\section{Kesimpulan}

Berdasarkan hasil pembahasan maka dapat ditarik kesimpulan sebagai berikut :

1. Keberadaan sektor pertambangan mineral logam tidak memberikan peran langsung secara signifikan terhadap pertumbuhan ekonomi yang diukur dengan menggunakan PDB.

2. Laju pertumbuhan sektor pertambangan logam setiap tahun rata-rata meningkat sebesar $1,83 \%$.

3. Pelarangan ekspor sektor pertambangan mineral logam dalam bentuk mentah sudah diberlakukan sejak terbitnya UU tersebut, sehingga untuk sementara waktu untuk 
beberapa tahun ke depan kontribusi sektor pertambangan logam terhadap PDB mengalami penurunan, yaitu sebesar $1,23 \%$.

4. Besarnya kontribusi sektor pertambangan mineral logam sebesar $1,04 \%$, apabila tidak ada upaya untuk mengelola sumber daya mineral logam ke arah yang lebih baik dikhawatirkan peran sektor ini akan terus menurun.

\section{Saran}

Untuk meningkatkan laju pertumbuhan dan kontribusi sektor pertambangan mineral logam yang menurut perkiraan hingga tahun 2029 hanya sebesar $1,83 \%$ per tahun, maka faktorfaktor produksi yang harus ditingkatkan adalah kapasitas pengolahan dan pemurnian mineral logam, mengoptimalkan kandungan lokal dari kegiatan sektor pertambangan mineral logam dan memberikan insentif bagi pengembangan pengolahan produk pertambangan di sektor pertambangan mineral logam.

\section{UCAPAN TERIMA KASIH}

Pada kesempatan ini, ucapan terima kasih disampaikan kepada semua pihak lembaga/instansi maupun pribadi yang telah memberikan saran dan masukan, baik langsung maupun tidak langsung sehingga terwujudnya hasil kajian ini dan semoga pula kajian ini bermanfaat bagi para pelaku usaha mineral logam, peneliti dan pemerhati mineral logam.

\section{DAFTAR PUSTAKA}

Arisandi, R. dan Purhadi (2014) "Estimasi parameter dan pengujian hipotesis model regresi Burrtiga parameter tipe XII," in Prosiding Seminar Nasional Matematik a, Universitas Jember. Jember: Universitas Jember, hal. 145-166.

BPS (2016a) PDB Indonesia menurut lapangan usaha tahun 2000 - 2014 atas dasar harga konstan tahun 2000. Badan Pusat Statistik.

BPS (2016b) Pendapatan Indonesia tahun 20112015 atas dasar harga tahun 2010. Badan Pusat Statistik.
Gaspersz, V. (1992) Analisis sistem terapan berdasarkan pendekatan teknik industri. Bandung: Tarsito.

Gujarati, D. N. (2003) Basic economtrics. 4th Ed. New York: McGraw-Hill Companies.

Haeruman, D. H. (2014) Analisis perkembangan produk domestik bruto (PDB) Indonesia tahun 1973-2013 berdasarkan komponen pengeluaran. Institut Teknologi Bandung.

Hermawan, H. R. (2014) Pengaruh sektor pertambangan terhadap pertumbuhan ekonomi dan pembangunan manusia. Institut Pertanian Bogor. Tersedia pada: https://docplayer.info/60953125-Pengaruhsektor-pertambangan-terhadap-pertumbuhanekonomi-dan-pembangunan-manusia-hardy-rhermawan.html.

Hidayat, W., Rustiadi, E. dan Kartodihardjo, H. (2014) "Dampak sektor pertambangan terhadap perekonomian wilayah di Kabupaten Luwu Timur," Jurnal Economia, 10(1), hal. 65-80. Tersedia pada: https://journal.uny.ac.id/index.php/economia/ article/view/4095.

Idris, F. (2008) Faktor-faktor yang mempengaruhi produk domestik regional bruto (PDRB) di Kabupaten Labuhan Batu. Universitas Sumatera Utara.

Istiarini, R. dan Sukanti (2012) "Pengaruh sertifikasi guru dan motivasi kerja guru terhadap kinerja Guru SMA Negeri 1 Sentolo Kabupaten Kulon Progo Tahun 2012," Jurnal Pendidikan Akuntansi Indonesia, 10(1), hal. 98-113. doi: 10.21831/jpai.v10i1.924.

Kira, A. R. (2013) "The factors affecting gross domestic product (GDP) in developing countries: The case of Tanzania," European Journal of Business and Management, 5(4), hal. 148-158. Tersedia pada:

https://iiste.org/Journals/index.php/EJBM/articl e/view/4476.

Kustanto, H., Oktaviani, R., Sinaga, B. M. dan Firdaus, M. (2012) "Reindustrialisasi dan dampaknya terhadap ekonomi makro serta kinerja sektor industri di Indonesia," Jurnal Riset Industri, 6(1), hal. 97-115. Tersedia pada:

http://ejournal.kemenperin.go.id/jri/article/vie w/3298.

Mayanti, A., Syaparuddin, S. dan Ahmad, E. (2013) "Analisis PDRB sektor primer dan kesempatan kerja di Kabupaten Bungo," Jurnal Perspektif Pembiayaan dan Pembangunan Daerah, 1(1), 
hal. 51-62. Tersedia pada: https://onlinejournal.unja.ac.id/index.php/JES/article/view/ 1342.

Melati, A. (2013) "Faktor-faktor yang mempengaruhi tingkat sewa sukuk ijarah," Accounting Analysis Journal, 2(2), hal. 233242. Tersedia pada:

https://journal.unnes.ac.id/sju/index.php/aaj/a rticle/view/2920.

Raswatie, F. D. (2014) “Hubungan ekspor-impor produk domestik bruto (PDB) di sektor pertanian Indonesia," Jurnal Ekonomi Pertanian, Sumberdaya dan Lingkungan, 1(1), hal. 28-42. Tersedia pada:

http://journal.ipb.ac.id/index.php/jaree/article/ view/11288/8790.

Saheed, Z. S., Abarshi, J. A. dan Ejide, I. S. (2014) "Impact of petroleum tax on economic growth in Nigeria (1970-2012)," International Journal of Education and Research, 2(11), hal. 297-308. Tersedia pada:

https://www.ijern.com/journal/2014/Novemb er-2014/25.pdf.

Sudjana (2005) Metoda statistika. Bandung: Tarsito.

Sulaksono, A. (2015) "Pengaruh investasi dan tenaga kerja terhadap PDB sektor pertambangan di Indonesia," Jurnal Elektronik, 20(1), hal. 16-24. Tersedia pada: https://ejournal.gunadarma.ac.id/index.php/ek bis/article/view/1151/0.

Sundari, W. (2012) Analisis pertumbuhan industri non migas terhadap pertumbuhan domestik bruto (PDB) di Indonesia tahun 2007-2012, www.academia.edu. Tersedia pada: https://www.academia.edu/13101820/analisis _pertumbuhan_industri_terhadap_pertumbuh an PDB Indonesia (Diakses: 31 Oktober 2016).

Supranto, J. (1983) Ekonometrik. 1st Ed. Jakarta: Lembaga Penerbit Fakultas Ekonomi Universitas Indonesia.

Yudisthira, I. M. dan Budhiasa, I. G. S. (2013) "Analisis pengaruh konsumsi, investasi, dan inflasi terhadap produk domestik bruto di Indonesia tahun 2000-2012," E-Jurnal Ekonomi Pembangunan, 2(11), hal. 492-546. Tersedia pada: https://ojs.unud.ac.id/index.php/eep/article/vi ew/6497.

Yulianita, A. (2009) "Analisis sektor unggulan dan pengeluaran pemerintah di Kabupaten Ogan Komering Ilir," Journal of Economic and Development Policy, 7(2), hal. 70-85. Tersedia pada: https://ejournal.unsri.ac.id/index.php/jep/artic le/view/4878.

Zulkarnain, M., Purwanti, P. dan Indrayani, E. (2013) "Analisis pengaruh nilai produksi perikanan budidaya terhadap produk domestik bruto sektor perikanan di Indonesia," ECSOFIM, 1(1), hal. 52-68. Tersedia pada: https://ecsofim.ub.ac.id/index.php/ecsofim/art icle/view/13. 
Derajat kebebasan untuk pembilang

\begin{tabular}{lllllllllllllllllll}
\hline 1 & 2 & 3 & 4 & 5 & 6 & 7 & 8 & 9 & 10 & 12 & 15 & 20 & 24 & 30 & 40 & 60 & 120 & $\omega$ \\
\hline
\end{tabular}

$\begin{array}{lllllllllllllllllll}1161 & 200 & 216 & 225 & 230 & 234 & 237 & 239 & 241 & 242 & 244 & 246 & 248 & 249 & 250 & 251 & 252 & 253 & 254\end{array}$ $\begin{array}{llllllllllllllllllll}2 & 18.5 & 19.0 & 19.2 & 19.2 & 19.3 & 19.4 & 19.4 & 19.4 & 19.4 & 19.4 & 19.4 & 19.4 & 19.4 & 19.5 & 19.5 & 19.5 & 19.5 & 19.5 & 19.5\end{array}$

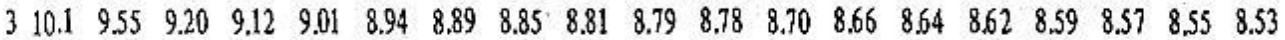
$\begin{array}{llllllllllllllllllll}4 & 7.11 & 6.94 & 6.59 & 6.39 & 6.26 & 6.16 & 6.09 & 6.04 & 6.00 & 5.96 & 5.91 & 5.86 & 5.80 & 5.77 & 5.75 & 5.72 & 5.69 & 5.66 & 5.63\end{array}$

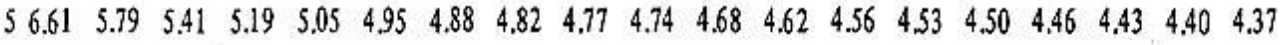

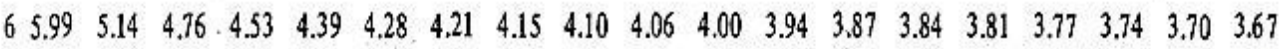
$\begin{array}{lllllllllllllllllll}75.59 & 4.74 & 4.35 & 4.12 & 3.97 & 3.87 & 3.79 & 3.73 & 3.68 & 3.64 & 3.57 & 3.51 & 3.44 & 3.41 & 3.38 & 3.34 & 3.30 & 3.27 & 3.23\end{array}$ $\begin{array}{llllllllllllllllllll}8 & 5.32 & 4.46 & 4.07 & 3.84 & 3.69 & 3.58 & 3.50 & 3.44 & 3.39 & 3.35 & 3.28 & 3.22 & 3.15 & 3.12 & 3.08 & 3.04 & 3.01 & 2.97 & 2.93\end{array}$ $\begin{array}{llllllllllllllllllll}9 & 5.12 & 4.26 & 3.86 & 3.63 & 3.48 & 3.37 & 3.29 & 3.23 & 3.18 & 3.14 & 3.07 & 3.01 & 2.94 & 2.90 & 2.86 & 2.83 & 2.79 & 2.75 & 2.71\end{array}$

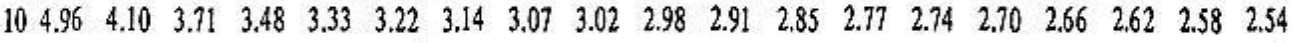
$\begin{array}{llllllllllllllllllll}11 & 4.84 & 3.98 & 3.59 & 3.36 & 3.20 & 3.09 & 3.01 & 2.95 & 2.90 & 2.85 & 2.79 & 2.72 & 2.65 & 2.61 & 2.57 & 2.53 & 2.49 & 2.45 & 2.40\end{array}$ $\begin{array}{llllllllllllllllllll}12 & 4.75 & 3.89 & 3.49 & 3.26 & 3.11 & 3.00 & 2.91 & 2.85 & 2.80 & 2.75 & 2.69 & 2.67 & 2.54 & 2.51 & 2.47 & 2.43 & 2.38 & 2.34 & 2.30\end{array}$

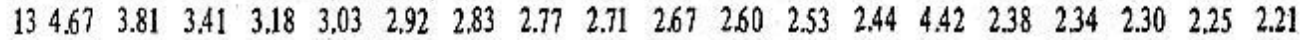
$\begin{array}{llllllllllllllllllll}14 & 4.60 & 3.74 & 3.34 & 3.11 & 2.96 & 2.85 & 2.76 & 2.70 & 2.65 & 2.60 & 2.53 & 2.46 & 2.39 & 2.35 & 2.31 & 2.27 & 2.22 & 2.18 & 2.13\end{array}$

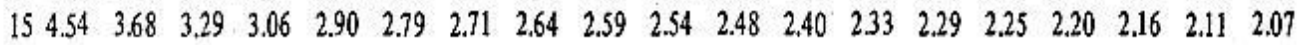

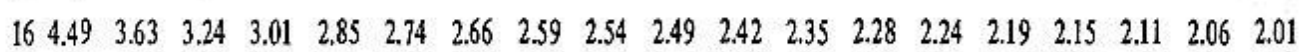
$\begin{array}{llllllllllllllllllll}17 & 4.45 & 3.59 & 3.30 & 2.96 & 2.81 & 2.70 & 2.61 & 2.53 & 2.49 & 2.45 & 2.38 & 2.31 & 2.33 & 2.19 & 2.15 & 2.10 & 2.06 & 2.01 & 1.94\end{array}$ $\begin{array}{llllllllllllllllllll}18 & 4.41 & 3.55 & 3.16 & 2.93 & 2.77 & 2.66 & 2.58 & 2.51 & 2.46 & 2.41 & 2.34 & 2.27 & 2.19 & 2.15 & 2.11 & 2.06 & 2.02 & 1.97 & 1.92\end{array}$ $\begin{array}{llllllllllllllllllll}19 & 4.38 & 3.52 & 3.13 & 2.90 & 2.74 & 2.63 & 2.54 & 2.48 & 2.42 & 2.38 & 2.31 & 2.23 & 2.16 & 2.11 & 2.07 & 2.03 & 1.98 & 1.93 & 1.88\end{array}$

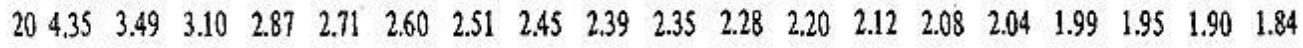
$\begin{array}{llllllllllllllllllll}21 & 4.32 & 3.47 & 3.07 & 2.84 & 2.68 & 2.57 & 2.49 & 2.42 & 2.37 & 2.32 & 2.25 & 2.18 & 2.10 & 2.05 & 2.01 & 1.96 & 1.92 & 1.87 & 1.81\end{array}$ $\begin{array}{llllllllllllllllllll}22 & 4.30 & 3.44 & 3.05 & 2.82 & 2.66 & 2.55 & 2.46 & 2.40 & 2.34 & 2.30 & 2.23 & 2.15 & 2.07 & 2.03 & 1.98 & 1.94 & 1.89 & 1.84 & 1.78\end{array}$ $\begin{array}{llllllllllllllllllll}23 & 4.28 & 3.42 & 3.03 & 2.80 & 2.64 & 2.53 & 2.44 & 2.37 & 2.32 & 2.27 & 2.20 & 2.13 & 2.05 & 2.01 & 1.96 & 1.91 & 1.86 & 1.81 & 1.76\end{array}$

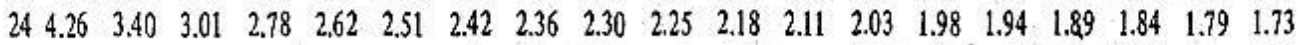

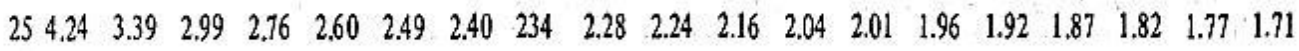

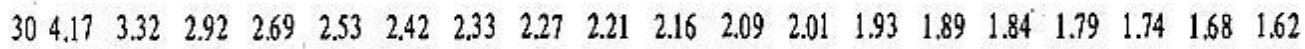

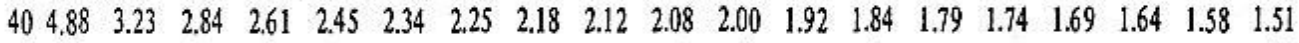

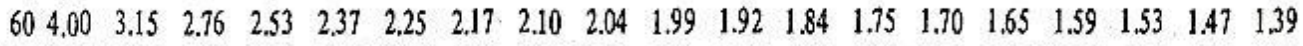

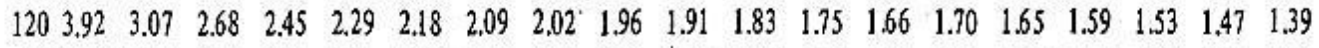
$\begin{array}{llllllllllllllllllll}\omega & 3.84 & 3.00 & 2.60 & 2.37 & 2.21 & 2.10 & 2.01 & 1.94 & 1.88 & 1.83 & 1.75 & 1.67 & 1.57 & 1.52 & 1.46 & 1.39 & 1.32 & 1.22 & 1.20\end{array}$ Sumber : Supranto (1983) 